\title{
Nacionalismo, globalización y cultura escolar: láminas murales para la enseñanza de la historia (1860-1939)
}

Nationalism, Globalization and School Culture: The Wall Charts for the Teaching of the History (1860-1939)

\author{
María del Mar del Pozo Andrés \\ Universidad de Alcalá (España) \\ mar.delpozoandres@gmail.com
}

\begin{abstract}
Resumen
En este artículo se exploran nuevas fuentes para la historia de la educación. Dentro del amplio ámbito de objetos que formaban parte del "ajuar" del aula, unos de los menos conocidos y nada estudiados en la historiografía educativa española son las colecciones de láminas para la enseñanza de la historia de España. Este trabajo pretende ser una primera aproximación al estudio de estas láminas didácticas de Historia utilizadas en las escuelas españolas y a su posible instrumentalización para la creación de identidades nacionales. Se plantea, en primer lugar, la genealogía de este material escolar y las recomendaciones que sobre su empleo se realizaron desde la cultura pedagógica; en segundo término, se realiza una aproximación a las colecciones iconográficas elaboradas para el aprendizaje de la asignatura de historia de España y localizadas hasta este momento, analizando qué idea de nación pretendían transmitir sus imágenes; y, finalmente, se formulan algunas hipótesis sobre la globalización que adquirió este material, al abrirse hacia las colecciones alemanas de historia de la civilización y el posible impacto que éstas pudieron tener en las aulas españolas.
\end{abstract}

Palabras clave: Láminas didácticas, Enseñanza de la Historia de España, Historia de la Escuela.

\begin{abstract}
In this article new sources for the study of the History of Education are explored. Amongst the wide variety of artefacts that were inside the classroom, one that remains unknown and was never studied in the Spanish educational historiography is the collection of wall charts for learning the History of Spain. This paper intends to be a first approach to the History wall charts used in the Spanish primary schools and their function in constructing national identities. The article has three parts. In the first
\end{abstract}

Abstract 
part we analyse the genealogy of this school material and the recommendations given from pedagogical culture about its use inside the classroom. In the second part we explore several iconographical series - the ones we have found till the moment - that were made specifically for the subject of History of Spain. We will research the implicit idea of nation that is shown through their images. In the third part we will formulate several hypothesis about the globalization of the wall charts, on the basis of the German series devoted to History of Civilization that were introduced into Spanish classrooms.

Key words: Wall charts, Teaching of the History of Spain, History of Schooling.

\section{Nuevos campos en historia de la educación: la cultura material de la escuela}

En los últimos diez años ha irrumpido con fuerza en la historiografía educativa el término de "cultura escolar", un concepto recogido del campo de la sociología de la educación y ampliamente utilizado a partir de los años setenta. Desde los modelos de sociología organizacional se define la "cultura escolar" como "las asunciones básicas, normas, valores y herramientas culturales que son compartidas por los miembros de la escuela y que influyen en su funcionamiento" (Maslowski, 2001: 8 y ss.). Las asunciones básicas son las creencias inconscientes, invisibles, inamovibles, que los profesores perciben como "verdaderas" y que orientan sus actividades cotidianas. Los valores y normas actúan en un nivel más claro de conciencia, y entran en la esfera de lo deseable o lo que se concibe como importante para la escuela, que generalmente constituye el cuerpo de "reglas no escritas" de comportamiento. Las herramientas y las prácticas culturales - como las costumbres, los símbolos, los mitos y los rituales - son pautas muy visibles, pero no fácilmente descifrables, a través de las cuales se "visualizan" las asunciones básicas, las normas y los valores de cada escuela. Este amplio modelo puede ser asumido e integrado en el planteamiento etnohistórico elaborado por el profesor Agustín Escolano y que él denomina "cultura empírica de la escuela", definida "por las prácticas que los enseñantes han inventado y difundido en el ejercicio de su profesión y que han llegado a configurar la memoria corporativa del oficio docente", incluyéndose también "las pautas en las que se han ejercitado los alumnos en las actividades de aprendizaje y formación" (Escolano, 2008: 123).

Este marco teórico permite nuevos enfoques en el estudio del nacionalismo a través de la cultura escolar, lo que significa un acercamiento al problema de la construcción de la identidad nacional desde la perspectiva de los sujetos de la educación, es decir, de los profesores que contribuyeron a la creación y transmisión de determinadas ideas de España desde la escuela y de los alumnos que asumieron, interiorizaron y/o rechazaron esos signifi- 
cados y aprendieron sus propias formas de "ser español". Esto nos lleva a repensar las escuelas como espacios de representación de un imaginario de la nación en el que el pasado y el futuro se encuentran y articulan en un presente instantáneo. Trazos del pasado como las memorias colectivas de conmemoraciones y celebraciones patrióticas, rituales en torno a la bandera, cánticos de himnos o prácticas didácticas sobre los contenidos históricos, cívicos o patrióticos impartidos en las escuelas pueden ayudarnos a encontrar evidencias de cómo se acercaba la nación española a los niños. Pero también el análisis de los objetos que constituían "el ajuar" de la escuela (Costa Rico, 2006: 197) y su utilización como elementos simbólicos en la vida cotidiana nos permiten nuevas formas de exploración sobre cómo se vivía España en las aulas. Aproximaciones como la decoración de las clases, las linternas mágicas, los mapas y las esferas, los billetes y medallas de premio, los grabados de los certificados y títulos; las reproducciones artísticas que adornaban los pasillos y vestíbulos de los colegios, o las "fotografías de clase", son el tema de algunas de las investigaciones internacionales más recientes en historia de la educación, integrándose en ese nuevo corpus de conocimientos que se ha dado en Ilamar "la cultura material de la escuela" o "las materialidades de la escuela". Un primer acercamiento a ella nos permite experimentar lo que el historiador holandés Huizinga denominó "una sensación histórica", término que define el sentimiento que uno tiene de conectar con su propio pasado a través del contacto con estos objetos (Dane, Earle y Van Ruiten, 2011: 264).

Una segunda aproximación a la cultura material de la escuela nos permite partir de los objetos, los artefactos o las tecnologías escolares para analizar sus significaciones culturales, su ubicación en los escenarios institucionales y sus relaciones con los actores y las prácticas empíricas de la enseñanza (Escolano, 2007: 17). Se entienden asimismo estos objetos como la forma material de las ideas y de los discursos, no sólo acerca de la organización del aula, sino también —en palabras de Walter Benjamin— sobre cómo las personas usan, consumen y construyen la cultura material en relación con los espacios sociales que habitan y con sus ocupaciones cotidianas (Lawn y Grosvenor, 2005: 10). Pero desde estas "microhistorias" locales, los estudios sobre la cultura material nos permiten abordar problemas de alcance global, como la industrialización, la circulación de ideas pedagógicas o la construcción de identidades nacionales y transnacionales.

Un ejemplo de estas afirmaciones lo constituyen las láminas didácticas o carteles que se utilizaron a partir de mediados del siglo XIX para introducir en las aulas los principios de la enseñanza intuitiva. Fue éste un material tremendamente popular en las escuelas de todo el mundo, sirviendo no sólo como instrumento de aprendizaje, sino también como elemento decorativo de las paredes de las clases. En España carecemos de investigaciones sobre estos objetos, salvo algunas referencias colaterales (Ruiz-Castell, 2008: 519-527) y desconocemos especialmente su uso como apoyo para la enseñanza de los contenidos escolares de Historia. 
Sin embargo, en otros países como Alemania, Holanda, Francia o Bélgica, ya existe una trayectoria investigadora en este ámbito (Stach, 2000; Willems, 1996; Van Oostrom, 1998; Dane, 2009; Cavanna, 2003; Catteeuw, 2005 y Depaepe, 2005), que ha dado lugar a un proyecto europeo sobre creación y circulación de láminas didácticas de Historia (Historic Wall Chart Website, 2010) y a varios congresos internacionales, como el de "Wall charts, history and European identity", celebrado en Würzburg (Alemania) en abril de 2009 (Grever, 2010: 64-69) y el de "Pictures and teaching: International perspectives" ( $13^{\text {th }}$ International Symposium of Museums of Education), celebrado en Rouen (Francia) en julio de ese mismo año.

Este trabajo pretende ser una primera aproximación al estudio de las láminas didácticas de Historia utilizadas en las escuelas españolas y a su posible instrumentalización para la creación de identidades nacionales. Me plantearé, en primer lugar, la genealogía de este material escolar y las recomendaciones que sobre su empleo se realizaban desde la cultura pedagógica; en segundo término, profundizaré en las colecciones iconográficas elaboradas para el aprendizaje de la asignatura de Historia de España, analizando qué idea de nación pretendían transmitir sus imágenes; y, en un tercero, plantearé la globalización de este material con su apertura hacia las colecciones alemanas de historia de la civilización y el posible impacto que éstas pudieron tener en las aulas españolas.

\section{Genealogía de las láminas y carteles como material didáctico para la enseñanza de la historia en las escuelas españolas}

Los investigadores centroeuropeos consideran que el origen de estas láminas son las ilustraciones de los libros de texto y manuales escolares, que, con la ayuda de las nuevas tecnologías de impresión, pudieron ampliarse, colorearse y producirse en masa. Su origen entroncaría con Comenio, quien ya era partidario en el siglo XVII de llenar las paredes de las clases con cuadros y tablas, y con los principios pedagógicos pestalozzianos del aprendizaje por intuición, siendo Basedow uno de los educadores pioneros en utilizarlas, allá por 1776. Sin embargo, la historiografía francesa sitúa el origen de su uso en las escuelas con la aparición del sistema mutuo de enseñanza. Lo que perseguían estos primeros carteles no era la realización de una pedagogía visual, sino la fijación de los contenidos que se aprendían en los semicírculos y, de hecho, estaban llenos de texto y no de imágenes. Sería la extensión de la enseñanza simultánea, allá por la década de 1840, la que trajese consigo unos nuevos y conocidos carteles de pesos y medidas, pensados para introducir en las escuelas el Sistema Métrico Decimal (Institut National de Recherche Pédagogique, 2009: s.p.). En los años posteriores 
los carteles y las láminas didácticas pudieron generalizarse gracias a los progresos tecnológicos, de manera que ya en 1870 había un gran mercado internacional, sobre todo de carteles para apoyar lecciones de Religión, Geografía, Historia y Ciencias Naturales, con un estatus metodológico diferente al de los manuales escolares y un significado didáctico ligado a la enseñanza oral dentro del aula (Uphoff, 2009).

Esta realidad se puso de manifiesto en las exposiciones universales del siglo XIX, a las que cada país concurrió con sus materiales de enseñanza más avanzados. No es muy aventurado suponer que fue en dichos eventos donde los educadores españoles entraron en contacto por primera vez con estas láminas. El pedagogo Mariano Carderera, observador en la Exposición Universal de Londres de 1862, destacó los carteles y estampas presentados por Inglaterra y los Países Bajos para las aún denominadas "lecciones de objetos", mientras que de Bélgica y Sajonia le llamaron la atención los de la "historia nacional". En general, consideraba que todos ellos "contribuyen mucho a facilitar la enseñanza pero por exacta que sea la representación de los objetos, nunca sustituye completamente a la realidad" (Carderera, 1863: 161). Francisco Javier Cobos, otro observador pedagógico en la Exposición Universal de París de 1867, destacó las colecciones de láminas y cuadros de historia alemana y príncipes sajones exhibidas por Sajonia y elaboradas por Schäfer y Grösse, que sustituían a los libros de texto y de las que se manifestó totalmente entusiasta, lamentando que España no hubiese aportado colecciones parecidas, salvo dos para la enseñanza intuitiva de la Historia Sagrada, elaboradas de forma más o menos artesanal por dos sacerdotes, con textos manuscritos y unos precios excesivos en comparación con el material de otros países (Cobos, 1869: 32). El estudio del catálogo de objetos presentados por España en dicha Exposición muestra la veracidad de estos comentarios, pues aparte de algunos carteles indeterminados impresos por la editorial Bastinos, el resto parecían láminas manuscritas confeccionadas por particulares y litografiadas de forma muy primitiva, estando destinadas al menos dos de ellas - firmadas por Marcos Álvarez, de Torralba (Ciudad Real) y Manuel Tolosa, de Madrid-a "facilitar la enseñanza de la Historia de España" (Exposition Universelle, 1867: 346 y 352). En eventos posteriores no se rompió esta tónica, presentándose sobre todo "cuadros sinópticos de la Historia de España" y lecciones litografiadas privadamente y con muy escasas posibilidades divulgativas.

Mi hipótesis inicial es que, a diferencia de lo que sostienen los investigadores de Centroeuropa, en España es difícil situar el origen de las láminas didácticas en las ilustraciones de los manuales escolares, muy escasas y de poca calidad a mediados del siglo XIX. Yo creo que, al igual que se ha apuntado para el caso francés, posiblemente podamos encontrar su antecedente más cercano en las lecciones "impresas o manuscritas" propias del sistema de enseñanza lancasteriano, las cuales, según podemos apreciar en los grabados de la época, colgaban en las paredes de las clases, de acuerdo con lo dispuesto en el Reglamento de 1838 
para las escuelas públicas. Hacia 1850, y coincidiendo también con la extensión del sistema simultáneo de enseñanza, se quiso dar una apariencia de modernidad a las aulas. Aquellas pocas escuelas que podían hacer ostentación de riqueza escogieron los mismos mecanismos seguidos por la burguesía para reflejar su estatus en los espacios privados: el abigarramiento, la exhibición de un costoso material, adquirido en el extranjero, no con propósitos docentes, sino con aspiraciones decorativas y de escaparate. La escuela característica de esta época era aquella que no dejaba un solo hueco vacío en sus paredes, todas ellas alicatadas hasta el techo con láminas de animales y objetos exóticos, dispuestas de forma armónica para simbolizar los principios de la racionalización escolar. Cuando al rededor de 1870 se pusieron de moda los Museos escolares, esas mismas láminas volvieron a desempeñar un papel que se les adjudicó en ese momento, el de ser la imagen física de las tecnologías del conocimiento basado en la intuición, un buen deseo que quedaba rápidamente oscurecido por la posición en la que colgaban, a una gran distancia del suelo para impedir que los niños las pudiesen ver o tocar.

El valor simbólico que tuvieron estos instrumentos didácticos en España, como iconos de una riqueza que muy pocas escuelas poseían, es el que, posiblemente, impulsase el rechazo que los pedagogos liberales y progresistas manifestaron hacia su presencia en las aulas, incluso aunque mantuviesen su funcionalidad educativa. Una voz tan autorizada como la de Manuel Bartolomé Cossío nos informa que a comienzos del siglo Xx este material colgaba de las paredes de las clases, favoreciendo la aparición de polvo y nidos de insectos, porque la escuela carecía de espacios para almacenarlo. "El clamor general" pedía su desaparición, por antiestético, antihigiénico y antipedagógico. Y justificaba esta afirmación recurriendo, precisamente, al ejemplo de las láminas existentes para la enseñanza de la historia sagrada y la de España, que, en general, representaban "escenas y retratos de mal gusto artístico y de muy dudosa exactitud arqueológica" (Cossío, 1915: 115-116).

Este posicionamiento rotundo de Cossío influyó en la postura del Museo Pedagógico Nacional, del que fue director, contraria a la utilización de carteles para la enseñanza de la Historia de España, y posiblemente fuese la razón de que la mayoría de los maestros nunca manifestasen excesivo entusiasmo por esta tecnología de la instrucción. Rafael Altamira denominaba a este material "cuadros históricos", en los cuales "se presentan escenas importantes o célebres de la vida de los pueblos, retratos de personajes, vistas de los monumentos debidos al arte y la industria humanos, etc.". Lo consideraba un material inadecuado pero necesario como representación, ante la ausencia y escasez de otro tipo de objetos reales, y como forma de asegurar que la enseñanza fuese siempre "intuitiva y realista". Sin embargo, criticaba gran parte de las colecciones de Historia de España realizadas en nuestro país, considerando que apenas existía ninguna a la que se pudiese considerar como "colección" y que la más popular, la de Paluzié, "no reúne condiciones recomendables". Se planteaba cómo conseguir que los dibujos aunasen a la vez la "belleza artística" y la "fidelidad histórica", 
inclinándose, aunque con dudas, por la reproducción de cuadros de grandes pintores, los cuales, si bien no alcanzaban a todos los hechos importantes ni guardaban la debida "fidelidad arqueológica", sí que tenían el "valor de idealidad, de representación imaginativa, que corresponde muy bien con la que el relato de los sucesos levanta en la fantasía de los alumnos, haciéndoles buscar una concreción plástica que fije sus imágenes" (Altamira, 1891: 188-190). En esta línea, le llamaban la atención los billetes de premio con escenas históricas presentados por las empresas francesas en la Exposición Universal de 1889 y que en España introduciría posteriormente la Casa Editorial Bastinos con sus colecciones de "Panorama universal", "Historia Universal" y "Hombres y Mujeres ilustres" (Bastinos, 1897: 187).

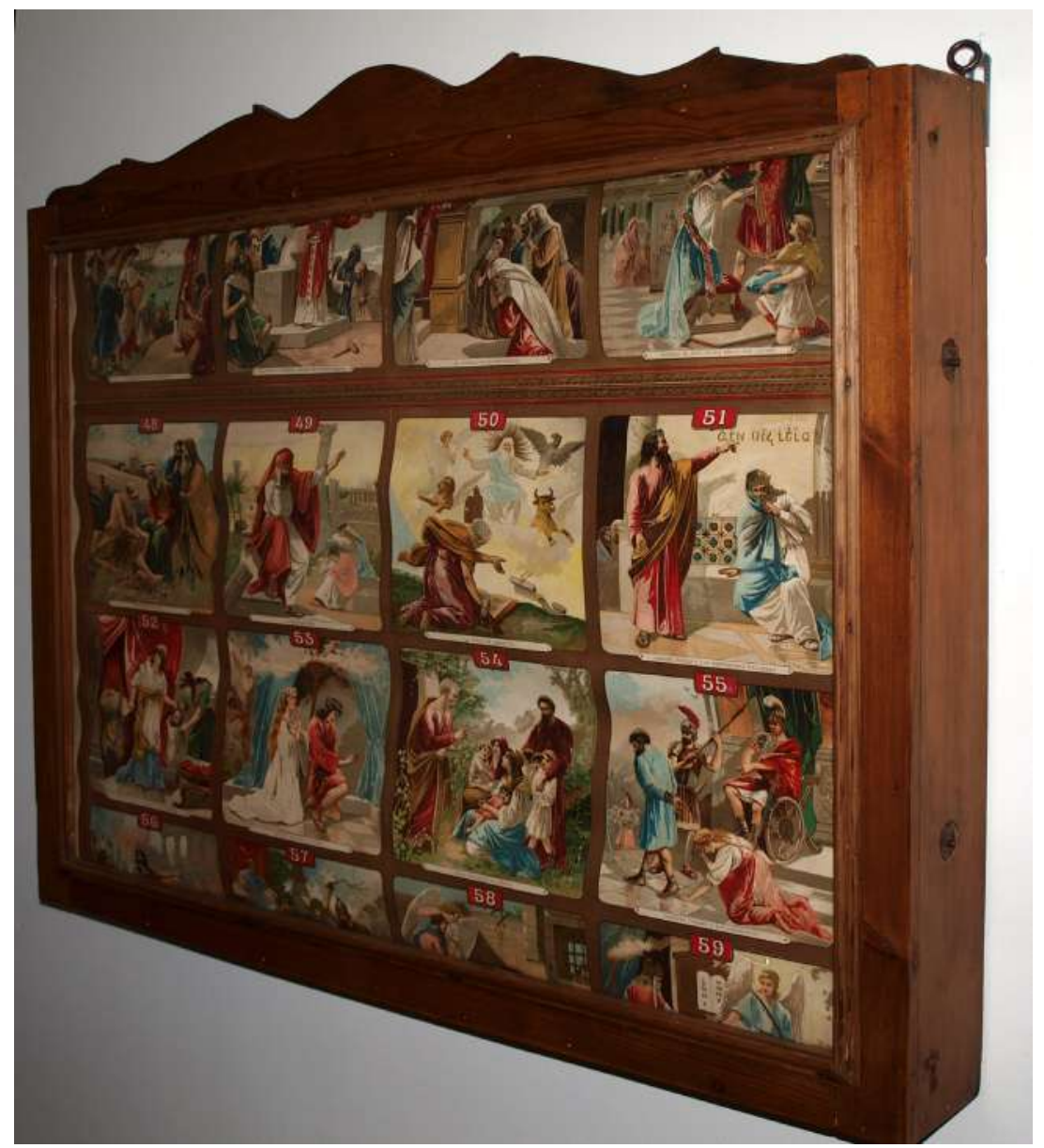

Figura 1. Láminas de historia sagrada con el aparato en el que se exponían 
El mayor inconveniente que Rafael Altamira encontraba en las colecciones europeas de "cuadros históricos" era su referencia exclusiva "a la historia particular de sus respectivas naciones", por lo que poco servían para enseñar la historia universal "y casi nada para la de España". Paseaba su mirada por las producciones más conocidas de toda Europa —cuadros de Meinhold, especiales para Alemania; los de Hartinger, para Austria; los de Buri y Jecker para Suiza; los famosos de Gérard en Bélgica, "notables, aunque algo teatrales"; "y las medianas cromolitografías holandesas de ljkema"-, con lo que demostraba su exhaustivo conocimiento de este material, y proponía que se realizase una selección de todos ellos, para formar una nueva colección "de interés general". También le llamaban mucho la atención las láminas en colores de M. Buschmann, de Amberes, "que representan personajes históricos en su traje verdadero", en cuyo diseño se había seguido fielmente las fuentes de cada época. Sin embargo criticaba, por su escaso valor pedagógico, "otro género de cuadros históricos que no representan escenas o personajes por medio del dibujo, sino series de hechos esquemáticamente", como los denominados "cuadros sincrónicos", que no eran sino listados cronológicos, salpicados de algunos mapas, para ubicar espacial y temporalmente cada hecho histórico.

En cualquier caso, Rafael Altamira nunca fue muy entusiasta de este material, aunque no dejaba de reconocer algunas de sus ventajas. Cuando en 1934 recordaba cómo se enseñaba habitualmente la Historia nacional en las escuelas españolas a finales del siglo XIX, criticaba su identificación con "un seco relato cronológico", la ausencia absoluta de mapas, fotografías, visitas o excursiones y la escasez de material, "todo lo más, algunas series insignificantes españolas o extranjeras, y no muy buenas, en general, de estampas en negro o en color, clavadas en la pared de una manera permanente". Daba a entender que estas láminas eran especialmente utilizadas por las maestras para ilustrar sus narrativas históricas, "para hacer descripciones más o menos vivas, que encendían en el espíritu del niño un poco de calor y de comprensión por la Historia" (Altamira, 1934: 40-41). Por eso, algunos autores recomendaban su empleo especialmente en la enseñanza de párvulos, pues para inculcar en estos infantes el entusiasmo por estos conocimientos, "es necesario que se presenten a su naciente, pero viva imaginación, cuadros muy animados de escogidos hechos históricos, no sólo bien escritos oralmente, sino que impresionen además el sentido de la vista por medio de láminas de correctos dibujos y con buen gusto iluminadas" (Miró, 1889: 194).

Rafael Altamira se inclinaba porque en las escuelas primarias no se enseñase Historia de España sino Historia de la Civilización, insinuando que la redacción del Real Decreto de 26 de octubre de 1901, firmado por el conde de Romanones y en el que se estableció el currículum obligatorio de las escuelas públicas que estuvo vigente hasta 1937, permitía abordar una nueva visión de esta materia. Efectivamente, en el plan de 1901 se implantó como obligatoria la asignatura de "Geografía e Historia", suprimiéndose la explicación introducida en 1857 de que estos contenidos debían ser "especialmente de España". Esta omisión permitía 
a los docentes concebir una Historia no exclusivamente nacional, e incluso abrirse hacia una Historia Universal, que Rafael Altamira entendía como Historia de la Civilización. Tal concepto transcendía la historia-batalla y la historia-política y englobaba, además del conocimiento de los personajes históricos, un estudio de la historia cultural y del progreso humano a lo largo de todas las épocas, con especial atención a los avances científicos y artísticos, pero también al desarrollo de la vida cotidiana en sus diferentes manifestaciones —vivienda, traje, alimentación, fiestas, costumbres, relaciones sociales, etc.-

El Museo Pedagógico Nacional impulsó esta noción de Historia de la Civilización a través de sus adquisiciones y recomendaciones sobre el material de enseñanza. En 1890 había recogido en sus fondos, además de varias colecciones alemanas e inglesas de Historia Sagrada, algunas otras de arte y conocimiento del mundo antiguo, procedentes también de Alemania. No parecía que nada de lo editado en España fuese adecuado para las escuelas, salvo las fotografías de monumentos y objetos de arte realizadas por Laurent, por lo que habían empezado a formar sus propias series de láminas al carbón sobre "Historia de la Civilización" e "Historia del traje", que en aquel momento estaban en fase de diseño y estudio. La primera se basaba en los dibujos de la obra francesa de Perrot y Chipiez, y la segunda en los del libro inglés de Godwin, Dress and its relation to health and climate (Museo Pedagógico de Instrucción Primaria, 1890: 81-83). Estas series, realizadas al lápiz y al carbón, posiblemente se terminasen pero parece que nunca se comercializaran, a pesar de los deseos expresados por algún editor madrileño de publicar colecciones calcadas sobre estos trabajos, para ser utilizadas en las escuelas primarias (Ballesteros, 1899: 339). El ya escaso entusiasmo inicial del Museo Pedagógico Nacional por los carteles y láminas no hizo sino disminuir, lo cual quedó muy patente en el dictamen que elaboró en 1913 sobre los modelos de material de enseñanza que el Ministerio de Instrucción Pública debería adquirir a partir de aquel momento para las escuelas nacionales. En el caso de Historia, se sugerían exclusivamente las excursiones y visitas, "pero como esto es hoy punto menos que imposible de realizar en nuestras escuelas", podían sustituirse con tarjetas postales y aparatos de proyección. Dos años después, en 1915, el Museo Pedagógico Nacional comenzó a recomendar, además, dos colecciones alemanas de "cuadros históricos", la de Lehmann, "Láminas de la historia de la civilización", que constaba de 34 elementos, y la de Lohmeyer, "Láminas murales para la enseñanza de la Historia", con 24 dibujos (Museo Pedagógico Nacional, 1915: 17-18).

La renuencia del Museo a utilizar carteles en las aulas, y especialmente a colgarlos de las paredes, tuvo un impacto tremendo en la cultura escolar española. En los años treinta, la imagen de una escuela renovadora se caracterizaba por la desnudez de sus paredes, adornadas solo con unas pocas fotografías, de buen tamaño, "que reproduzcan un paisaje, un monumento, clásico o moderno, un cuadro de los grandes maestros, una obra moderna de ingeniería,..." (Ballesteros y Sáinz, 1934: 72). Autores conservadores, como Agustín Serrano 
de Haro, se manifestaban contrarios a esas "famosas colecciones" de Historia de España, "único material vulgarizado, que aun afean los muros claros y sencillos de algunas escuelas", inclinándose por la utilización de fotografías y objetos reales recopilados por los propios maestros y que formasen "un verdadero museo histórico escolar" (Serrano de Haro, 1933: 48-49). Autores más progresistas, como Antonio Ballesteros y Fernando Sáinz, aunque no rechazaban totalmente el uso de las "láminas de historia" y de otras materias, quizás porque sabían lo extendidas que estas colecciones estaban ya en las escuelas, sí que recomendaban encarecidamente que no estuviesen colgadas de las paredes. "No combatimos el recurso didáctico" - llegaron a decir estos autores - "nosotros nos referimos al sistema permanente y con fines puramente decorativos", porque la clase no podía estar decorada con objetos instructivos. "Las láminas de historia [...], por razones pedagógicas y estéticas, no deben permanecer a la vista de los niños para que al ser utilizadas en el momento preciso conserven todo el interés de lo nuevo, de lo desconocido" (Ballesteros y Sáinz, 1934: 69). Es éste un ejemplo característico de esa "gramática de la escolarización" — según la conocida expresión de Tyack y Cuban- que adapta cualquier innovación educativa dentro de los límites de las culturas y tradiciones escolares. Los pedagogos progresistas, que, aparentemente, eran mejores conocedores de la escuela rural que los conservadores, no pretendían sustituir las láminas por materiales construidos por el docente, pues sabían el salto cualitativo que ello suponía y que sólo los maestros muy preparados podrían abordar, sino que sólo aspiraban a acabar con el mal uso que de estas láminas se hacía en la mayoría de las escuelas, ese uso puramente decorativo que se les adjudicó en 1850 y que había logrado extenderse hacia 1930, y se proponían que llegaran a utilizarse, como era habitual en Europa desde mediados del siglo XIX, como apoyo de la palabra del profesor en las lecciones orales de Historia.

\section{Las láminas de historia de España: la nación eterna}

En España carecemos aún de estudios sobre este tipo de material instructivo, por lo que todas las conclusiones que se establezcan en este trabajo son necesariamente provisionales. Sí que creo que puedo realizar tres afirmaciones como punto de partida. En primer lugar, la producción nacional de láminas de Historia de España fue una derivación o consecuencia de las elaboradas para la Historia Sagrada, no alcanzando nunca ni la difusión ni la variedad de estas últimas. Mientras que es posible localizar muchísimas series de Historia Sagrada, que fueron incluso exportadas a Europa y adquiridas por escuelas católicas de Bélgica y Holanda, la nómina de las colecciones de Historia de España, a falta de más estudios de conjunto, es reducida y muy circunscrita a editoriales madrileñas. En segundo término, casi todo el material rastreado fue elaborado en la segunda mitad del siglo XIX, reeditándose posteriormente y llegando hasta 
los años treinta, e incluso a las escuelas franquistas, con muy pocas variaciones. Por lo tanto, las imágenes producidas reflejan o se hacen eco, en general, de las corrientes historiográficas decimonónicas, y nunca fueron actualizadas. Finalmente, estas colecciones tardaron bastante en introducirse en las escuelas, por su elevado precio, y, cuando lo hicieron, los docentes carecían de pautas didácticas sobre cómo utilizarlas como apoyo de sus clases de Historia de España.

Las primeras láminas históricas que se adoptaron en las escuelas españolas fueron las de carácter cronológico. Destaca, por su rareza, el "cuadro simbólico" de la historia de España elaborado por Adèle Costes hacia 1830 y traducido del francés por Luís Bordas (Costes, ¿1830?), quien también adaptó la "guía para la inteligencia del mapa simbólico" (Costes, 1842). Era éste un ingenioso método de enseñar historia con veinte pliegos, correspondientes a cada uno de los siglos, que podían presentarse individualmente o montarse en un "impresionante y enorme mural en el que se puede ir, de un solo vistazo, desde la Hispania romana hasta la España de los Borbones" (Bouza, 2008: 42). Los hechos y fechas estaban "traducidos en signos materiales" y colores, con el objeto de que la historia fuera "aprendida por el órgano de la vista". A pesar de tan atractiva presentación, una lectura de la "guía" nos demuestra que se requería de los alumnos un enorme esfuerzo memorístico para el aprendizaje de reyes, fechas y hechos, que apenas eran descritos ni explicados. También alcanzó una cierta popularidad la "Carta Sincronológica de Historia Universal" de S. C. Adams, traducida del inglés por Francisco J. Zavala, impresa en México en 1884 y que representaba "los hechos más notables" desde Adán y Eva hasta el año 1882. La Casa Perlado, Páez y Ca, sucesores del conocido editor decimonónico Hernando, comercializaba y distribuía tanto el material de Costes como el de Adams a principios del siglo xx (Catálogo, 1909: 148-149). Este último, que constaba de catorce grandes hojas, debió de tener diferentes ediciones, pues en los inventarios de la Fundación Escuelas Selgas de Oviedo, inauguradas en 1915, figuraba como un solo cuadro de 750 × 80 cm (Terrón Bañuelos y Mato Díaz, 1992: 177). Quizás fuera éste el formato más generalizado, que se presentaba en un gran mural de papel fino y vida efímera, en el que se incluían decenas de palabras y dibujos difícilmente visibles salvo que los niños pegaran sus ojos al cartel. A pesar de sus escasas posibilidades didácticas, sí que se advierte una evolución en estos materiales desde la historia de hechos políticos hacia la historia cultural. Valga como ejemplo el "Gráfico de la Historia de España" elaborado por Alberto del Castillo Yurrita hacia 1929 y comercializado, entre otras, por la editorial Dalmáu Carles (Catálogo, 1934-1935: 180). En una hoja de 75 x 108 cm se incluían dieciséis pequeños mapas históricos, interrelacionados con tres columnas en las que se dibujaban 125 objetos cotidianos y artísticos y todo ello orlado exteriormente con 22 imágenes de monumentos famosos.

El modelo más extendido fue el de las láminas históricas seriadas, organizadas en diferentes hojas o carteles. Las primeras eran en blanco y negro y en papel muy fino, después se 
fabricarían las cromolitografiadas y montadas sobre cartones, tela y materiales más fuertes, con bastidores de madera y presentadas exteriormente como las colecciones de mapas. La pobreza de la producción editorial española se manifestaba en el formato que, casi sin excepción, adoptaron estas colecciones, que recogían diez o doce dibujos diferentes en cada lámina, muy reducidos y difícilmente visibles, incluso desde los primeros pupitres de la clase. Este esquema permitió a los impresores utilizar los mismos medios tecnológicos que para los grabados de los libros y para los billetes de premio, pero impidió elaborar materiales españoles de calidad, se depenía totalmente de las importaciones europeas, inservibles en el caso de los cuadros de Historia de España.

En un primer rastreo de este material he podido localizar pistas de nueve colecciones de editoriales diferentes, aunque ha sido imposible encontrar y estudiar todas ellas. La primera de la que tengo noticia fue publicada por J. González en 1867, en dos volúmenes, uno de texto explicativo y otro con 119 láminas pequeñas a carboncillo, que posiblemente se comercializasen posteriormente en forma de carteles con varias de esas láminas en cada uno de ellos (González, 1867). La segunda, también en blanco y negro, fue la editada por la librería de González y Ferriz en 1878 y elaborada en la litografía de Fernández (González y Ferriz, 1878), que constaba de 118 dibujos organizados en veinte láminas, con seis imágenes en cada una de ellas y un libro explicativo redactado por Baldomero Mediano (Mediano y Ruiz, 1878). Es posible que de esa misma litografía de Fernández saliese una "Historia General de España y sus Indias", con cuatro murales y 143 dibujos, que figuraba en los catálogos de material didáctico adquirido en la segunda mitad del siglo XIX para las escuelas de indianos de La Rioja (Zapater Cornejo, 2007: 231). En 1882, y con motivo de la Exposición Pedagógica que acompañó al Congreso, el propietario de la editorial "La Educación", la más antigua de España en comercializar material de enseñanza, presentó su colección de "Historia de España", que constaba de 16 carteles, divididos en ocho cuadros cada uno, lo que hacían un total de 128 dibujos, "perfectamente iluminados", impresos en tela acharolada y con un texto explicativo que se vendía separadamente (Sobrino y Dorado, 1882: 23). De las de Paluzié tengo noticias indirectas, además de por las críticas de Altamira, por la misma Exposición Pedagógica de 1882, en la que se presentó una colección de escudos de armas y el árbol cronológico de los reyes de España, salpicado de vistas de monumentos célebres (Rosado, 1882: 3). La Casa Perlado ofrecía en 1909 una "gran colección de láminas" de Historia de España, cromolitografiadas, que se componía de 16 carteles y 144 dibujos de asuntos "de los más principales de la Historia Patria, desde sus tiempos primitivos hasta nuestros días" (Catálogo, 1909: 148-149). La Casa Editorial de Juan Eimler anunciaba en 1925 una colección de diez láminas, con un solo tema en cada una de ellas y acompañadas de texto explicativo, que debió tener poco éxito, pues para 1934 había ya desaparecido de su catálogo (Catálogo, 1925: 49; Catálogo, 1934). Cinco se correspondían con monumentos 
arquitectónicos, desde la Alhambra hasta El Escorial, y las otras cinco eran reproducciones de cuadros de alto valor histórico y que tenían como protagonistas a Colón, el duque de Alba, Felipe III y la rendición de Breda. En 1933 la editorial Salvatella publicó una colección de láminas de Historia de la Civilización Española, cuyo carácter novedoso, fruto de los nuevos vientos políticos, se manifestaba en que impulsaban la actividad del niño, pues éste debía colorearlas y escribir el texto correspondiente. Otra innovación es que se complementaban con el manual escolar y con un cuaderno, presumiblemente de ejercicios.

Pero, desde luego, la colección de láminas de Historia de España más conocida y utilizada en las escuelas españolas fue la de la editorial Calleja (Ruiz Berrio y otros, 2002: 184). Posiblemente comenzara a divulgarse en la última década del siglo XIX, y constaba de diez láminas de 100 x 75 cm, con doce dibujos en cada una de ellas y un número total de 119 escenas, que se complementaban con un texto explicativo (Calleja, 1901). La propia editorial denominaba "pliego" a cada una de las diez láminas, quizás por una asociación inconsciente con las historias que se relataban en los pliegos de cordel que los buhoneros vendían y contaban, con grandes recursos mímicos, en las ferias y romerías. No sería de extrañar que las maestras utilizasen una escenografía parecida para narrar los acontecimientos descritos en las ilustraciones. Estas buscaban, a través de la elección de temas, de una esquematización del relato, de la simplificación, de la apelación al mundo de las emociones y del énfasis en determinados aspectos, transmitir aquellos valores que sustentaban el corpus de conocimiento histórico. Por eso, los autores y editores preferían aquellos cuadros que pudiesen crear ideales en el niño, más que los que contribuían a construir cognitivamente su conocimiento histórico. Los maestros, y sobre todo las maestras, es muy probable que no buscasen en ellos los grandes conceptos de nación, sino que sólo quisiesen crear impresiones indelebles en las mentes infantiles, que sirviesen para mostrar modelos de identificación válidos para sus alumnas, contribuyendo muchas veces a la formación de una autoimagen personal más que a la fabricación de una imagen colectiva nacional.

Los constructores de material educativo tenían la libertad de interpretar la historia nacional, y su enfoque fue, quizás, menos nacionalista de lo que se pretendía (Catteeuw, 2009). En el caso español, las tres colecciones que he podido consultar —J. González (1867), González y Ferriz (1878) y Calleja (1901), editada originariamente al rededor de 1890- parecen apoyar esta afirmación, aunque con ciertas matizaciones. Si bien es una narrativa de aquellos hechos que fueron bien definidos en la historiografía nacionalista isabelina, pueden encontrarse notables diferencias, no sólo en la descripción de algunos acontecimientos, sino también en su representación iconográfica.

El mensaje sobre la idea de España que nos transmiten estas láminas históricas es el mismo que aparecía en los manuales decimonónicos de enseñanza primaria, que entendían la idea de España "como un hecho natural y obvio": "España existe y existía sin más" (Maes- 
tro, 2005: 170 y 180). Esta existencia eterna de España obviaba el tener que dar explicaciones sobre su esencia como nación. El primer dibujo de J. González (1867) mostraba "el emblema, escudo y atributos con que se acostumbra a representar a la nación española". El león, las columnas de Hércules, un gran libro y la mujer sentada eran símbolos que se reproducían también en el dibujo inicial de González y Ferriz (1878), aunque no se apuntaba ninguna explicación sobre ellos (véase fig. 2).

Sabemos que, en torno a 1868, y con la caída de la monarquía, se popularizó una representación de España como una matrona con un león a sus pies (Menéndez Pidal de Navascúes y otros: 1999). Era éste el símbolo de la Hispania de Adriano, en el que la matrona, al igual que vemos en la Figura 2, esgrimía las armas típicas de los iberos: una lanza y un pequeño escudo redondo. El grabado de González y Ferriz (1878) desdobla en dos la imagen de la mujer: la guerrera con sus atributos y la matrona sentada con los suyos. El león, que a veces significaba el valor y la lealtad españolas, era la insignia de los reyes godos, y fue el primer animal que simbolizó la nación desde el siglo XII. Durante el trienio liberal, surgió una representación iconográfica en la que el león aparecía con el texto constitucional entre sus garras, como se observa en la Figura 2 (González, 1867). Sin embargo, en la Figura 3 (González y Ferriz, 1878), el que suponemos fuera el texto constitucional reposaba, abierto, en el halda

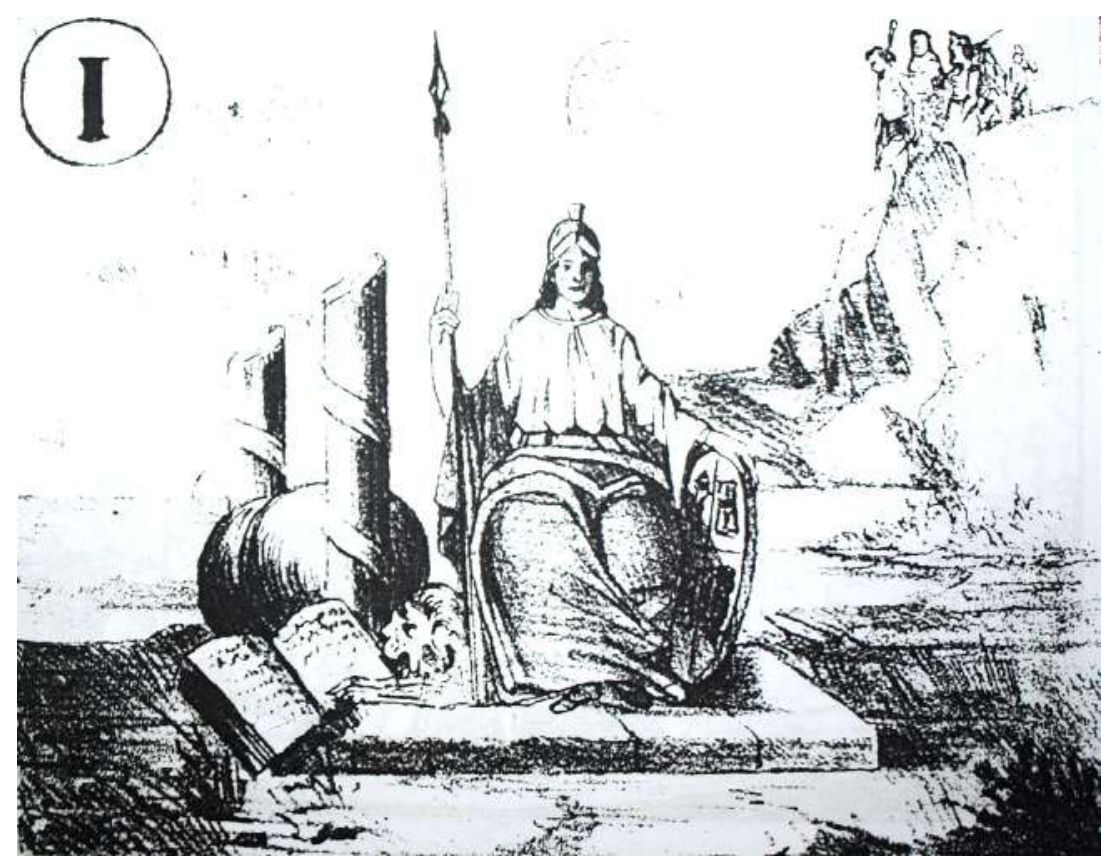

Figura 2. Representación de la nación española en la colección de láminas históricas de González (1867) 
de la matrona, quizás para marcar una distinción entre el imaginario de la Constitución de 1812 y el de la Constitución de 1876. El escudo era el icono de la unidad nacional desde la Hispania Romana y, precisamente, fue el gobierno de 1868 el que adoptó como emblema provisional aquel que perduraría hasta nuestros días, con los cuatro cuarteles representando a los reinos de Castilla, León, Aragón y Navarra y la punta con el símbolo de Granada. Sin embargo, la lámina de González y Ferriz (1878) sigue utilizando el escudo completo de Carlos III, recuperado por Fernando VII y, en su forma ovalada, utilizado especialmente en la época de Isabel II, ya concluida cuando se editaron las láminas (véase fig. 3). El de González (1867) puede que exhiba la versión simplificada de dicho escudo, también propia de los reinados fernandino e isabelino, o puede que utilice el de los cinco cuarteles establecido tras la revolución de 1868. El dibujo nos impide asegurarlo con certeza, aunque nos inclinamos por la primera hipótesis, pues sería harto extraño que el material escolar se adelantase en un año a las disposiciones del gobierno provisional. Finalmente, las columnas de Hércules, cruzadas en ambas imágenes con la cinta en la que se inscribía el lema "Plus Ultra", fueron introducidas en la iconografía de la nación en tiempos de Carlos I, como representación de las Indias

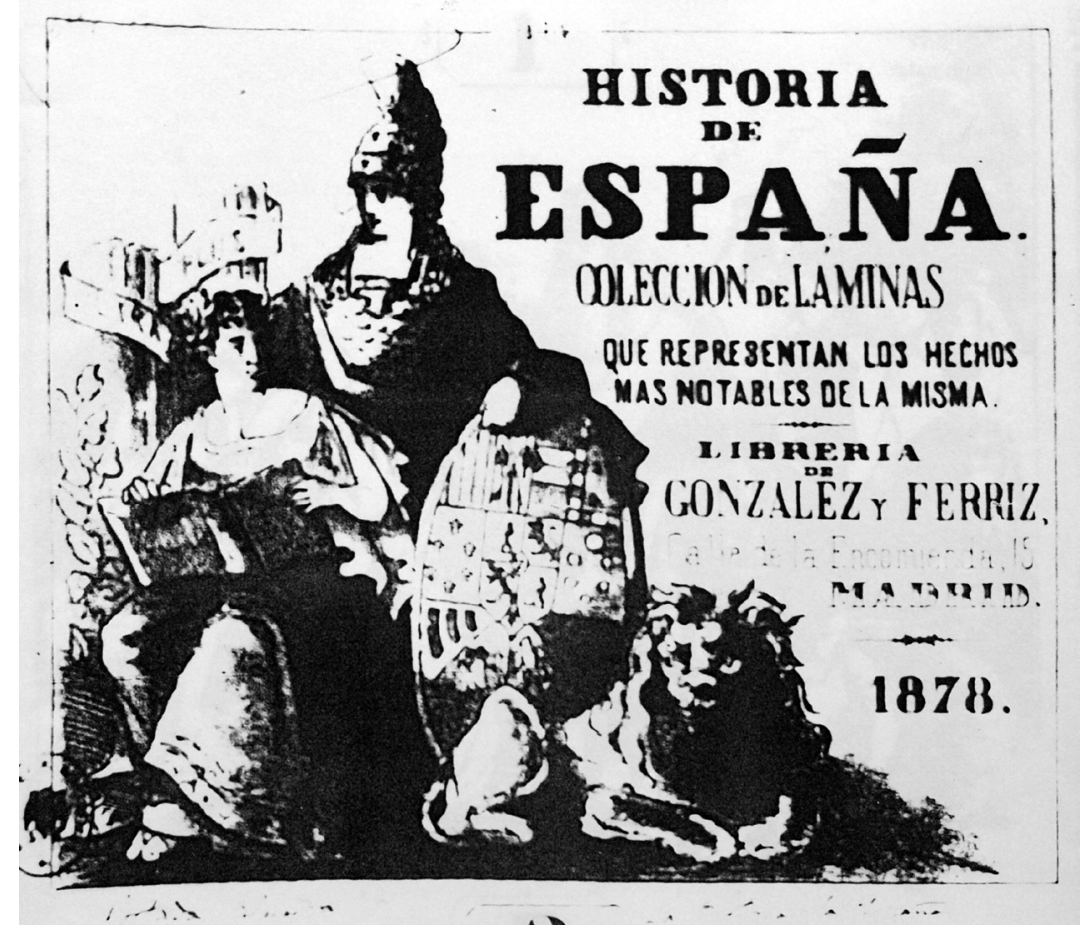

Figura 3. Representación de la nación española en la colección de láminas históricas de González y Ferriz (1878) 
y, en definitiva, del Imperio. Por la posición de todos estos símbolos en las imágenes parece que la de González (1867) ponía el acento en la representación de la Hispania romana, mientras que la de González y Ferriz (1878), dibujada después de la polémica por los símbolos del Sexenio Democrático, se inclinaba por el escudo como icono de la unidad nacional.

La más antigua de estas tres colecciones aún mantenía en su texto explicativo la leyenda de que "el primer poblador de España fue Túbal, hijo de Jafet y nieto del patriarca Noé", aunque tachándola de "fábula" y "simples conjeturas" (González, 1867: 3). Los hechos históricos comenzaban en las tres colecciones con la fundación de Cádiz por los fenicios, un acontecimiento descrito en clave de conquista guerrera por González, y en clave de civilización por los otros dos, especialmente por Calleja. El texto explicativo de este último dibujo abundaba en datos sobre el traje fenicio, una tónica que se mantendría en las láminas posteriores hasta llegar al siglo XV, y que nos demuestra la influencia que las recomendaciones del Museo Pedagógico Nacional tenían en la construcción del material escolar.

En cualquier caso, y más allá de los símbolos, este dibujo inicial servía para instilar en las mentes infantiles la idea de una España eterna y atemporal, existente desde el comienzo de los tiempos y con una unidad geográfica e histórica en la que la sucesión de acontecimientos y personajes eran solo hitos de un continuum unitario que caracterizaban y servían para identificar las diferentes etapas del pasado nacional. En los textos explicativos de las láminas se apuntaba que los griegos llegaron "a las costas de España"; los guerreros que contemplaban la muerte de Viriato eran "soldados españoles", vestidos "al uso de los españoles de aquella época"; los romanos, los bárbaros y los árabes llegaron en diferentes épocas, pero todos recalaron y se quedaron "en España"; las huestes que acompañaron a Pelayo en Covadonga eran "esforzados españoles" que restauraron "la monarquía española". Sin embargo, nunca se identificaba a los árabes con ninguna característica del país y, como la retórica de la época exigía la apelación a calificativos, encontramos definiciones tan curiosas como la descripción que se hacía de un hijo del moro Muza, "godo de origen y mahometano de profesión". Nótese que los "godos" no eran considerados "españoles", quizás por su derrota en Guadalete, mereciendo ese nombre sólo los que habían mantenido el "pensamiento de restaurar la patria" en Covadonga. La fundación de Navarra, Castilla, Aragón y Barcelona era también atribuida a españoles fugitivos de las huestes mahometanas, definiéndose estos reinos, en algunas ocasiones, como Estados. La famosa batalla de las Navas de Tolosa fue una victoria de las tropas españolas, pues los textos explicaban que, si bien se habían unido a ellas "algunos centenares de aventureros extranjeros", todos huyeron antes de empezar el combate, "no pudiendo soportar las fatigas de la guerra".

El rasgo definitorio de España como nación era, desde luego, y casi exclusivamente, la religión católica. Entre las primeras láminas estaba siempre "la venida a España del apóstol Santiago", que en el dibujo de Conzález y Ferriz (1878) llegaba ya vestido "con el extraño 
traje adoptado en lo sucesivo por todos los peregrinos" y conseguía muchísimas conversiones, de manera que, durante las persecuciones romanas, "España fue uno de los países que más sangre derramaron confesando la fé católica”. El largo recorrido por los reyes godos servía sobre todo para escenificar unas luchas de religión que, quizás no es muy aventurado suponer, llevaría a algunos docentes a establecer paralelismos con la contemporaneidad de los años sesenta y setenta del siglo XIX, cuando el magisterio de la Iglesia empezaba a verse amenazado por unas corrientes krausistas y librepensadoras fortalecidas especialmente durante el Sexenio Democrático. Resulta cuando menos curioso que las colecciones de González (1867) y González y Ferriz (1878) escogieran un asunto tan específico como es el de Amalarico maltratando a su esposa Clotilde, por no querer ésta abandonar el catolicismo y convertirse al arrianismo. Aquellos maestros, y sobre todo maestras, que se identificasen con el problema expuesto en la novela galdosiana La familia de León Roch, encontrarían en este dibujo suficientes elementos para ilustrar un modelo de mujer que se enfrentaba a su

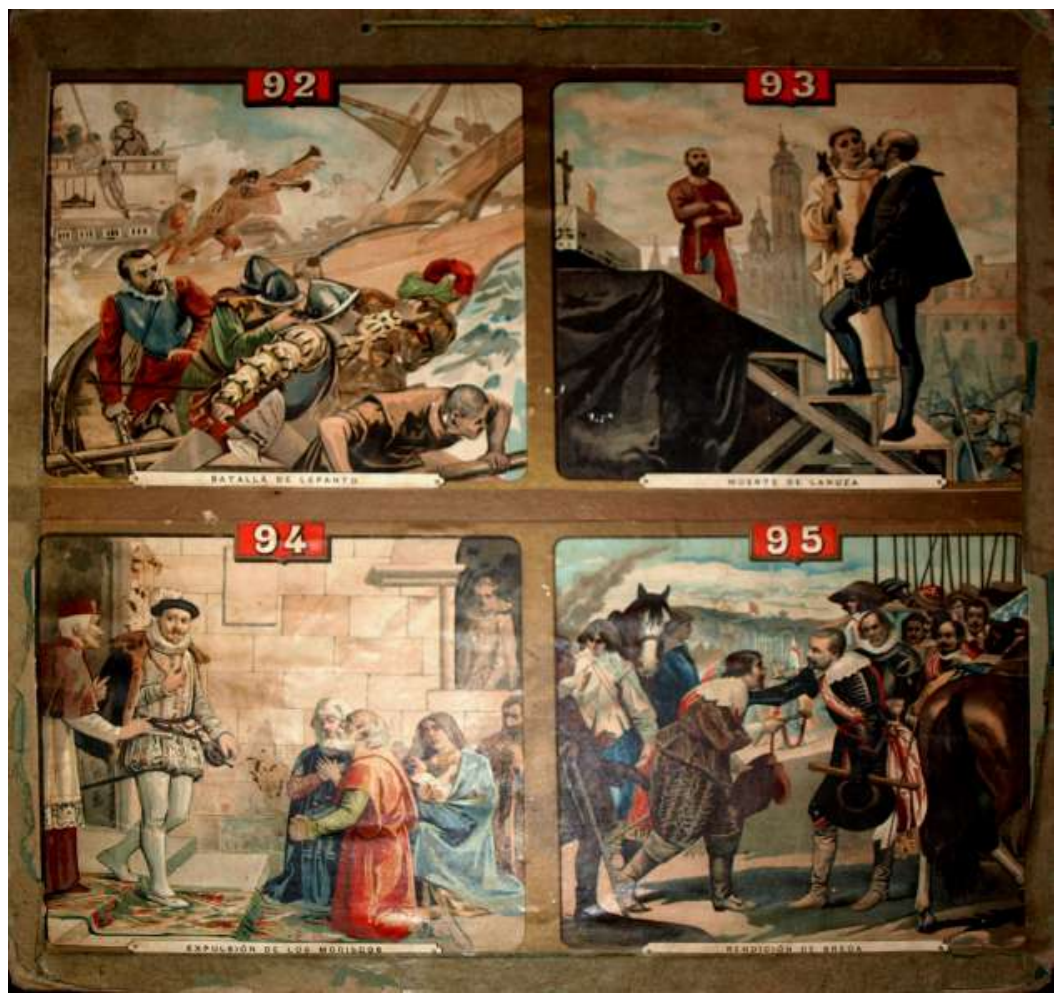

Figura 4. Representación de varias escenas, entre ellas la expulsión de los moriscos por Felipe III, en las láminas de Historia de España de Calleja 
marido por defender sus convicciones religiosas y, con sus palabras, intentarían que las niñas también se identificasen con este modelo.

Si las tres colecciones mantenían una línea clara de defensa de la religión católica como constitutiva del ser español, había una considerable disparidad entre ellas con respecto al tratamiento de las diferencias religiosas. Las tres se hacían eco de la expulsión de los moriscos por parte de Felipe III. Mientras que en la primera, la imagen les mostraba abandonando "España" a lomos de camellos, el texto justificaba tal medida, pues si "grande era la falta que habían de hacer tantos brazos a la agricultura y al comercio", era mucho más importante mantener "la piedad, el celo por la pureza de la religión" (González, 1867: 98). La serie de González y Ferriz (1878) recordaba también la expulsión de los judíos en tiempos de los Reyes Católicos, adjudicando la firma del edicto a Fernando. Sin embargo, la de Calleja mantenía una trayectoria constante de defensa de la tolerancia y crítica hacia los excesos cometidos en aras de la religión. Es la única que recoge la escena de la "expulsión de los judíos por el rey Sisebuto", representándoles en el cementerio, despidiéndose "de las cenizas de sus mayores" (Calleja, 1901: 14), una alegoría de la idea de patria que, aún sin decirlo, demostraba que Calleja los consideraba dignos del apreciado calificativo de "españoles". Ya en tiempos de la Reconquista, también es la única colección que incluye la "última víctima de la batalla de Alarcos", la judía Raquel de Toledo envuelta en amoríos con Alfonso VIII, a quien "algunos fanáticos" culparon de la derrota en la batalla y "quemaron viva a esta infeliz en Toledo; acto de barbarie representado en nuestra lámina, y que muestra hasta qué punto cegaba entonces a los hombres la intolerancia" (Calleja, 1901: 42). La expulsión de los judíos por los Reyes Católicos es aquí representada con una referencia no muy halagüeña a la Inquisición y una entrada espectacular de Torquemada al salón del Trono para acallar cualquier duda que los monarcas pudieran tener sobre esta decisión. Y la expulsión de los moriscos durante el reinado de Felipe III se explica desde la visión "del otro": "La lámina representa una comisión de estos infelices, que se presenta al Rey pidiéndole indulgencia" (Calleja, 1901: 99).

Las imágenes, al igual que los manuales de historia decimonónicos, se focalizan en aquellos individuos y acontecimientos singulares, de resistencia a la autoridad ciega o de defensa frente al enemigo exterior, que amenaza el territorio y las creencias religiosas. Así, la continua lucha de reconquista y sus excesos se justifican porque "el gobierno de los árabes y de los moros fue despótico" y "lo que más contribuyó al triunfo de las armas cristianas fue el sentimiento religioso" (González, 1867: 89). Sin embargo, se apela al "espíritu democrático" de las leyes de Aragón y Cataluña, manteniéndose la ilusión de que los monarcas cristianos tenían una forma de gobernar que, incluso, en algún momento, se califica de "republicana" por su talante democrático. Ahora bien, las luchas por la independencia que tanto se alaban en la Edad Media, se critican mucho más cuando ya no existe una justificación religiosa o un enemigo exterior más o menos pagano. Así, a los comuneros de Castilla no se 
les ve como unos mártires de la libertad, sino como unos personajes que montaron en cólera al ver a extranjeros ocupando cargos en el gobierno español y su muerte se califica, en un caso, de "ejecución", en otro, de "suplicio" y, en la colección de Calleja, simplemente se reproduce el célebre cuadro de Gisbert, sin hacer ningún juicio de valor sobre el tema.

Estas tres colecciones de láminas dibujan, fundamentalmente, sucesiones de reyes de todas las épocas, lo que puede entenderse como una representación de la monarquía como esencia de lo español. Pero también debemos tener en cuenta las limitaciones de la iconografía como medio de transmisión de la historia, al no poder pintar más que un hecho significativo de cada momento. Así es que suelen elegirse, quizás también por lo reducido del espacio y las exigencias de los dibujantes, escenas representativas de cada rey, que suelen coincidir con el momento de su fallecimiento. Estas series nos permiten apuntar la idea de que la finalidad de los editores no era tanto crear una conciencia histórica y nacional, como extraer enseñanzas morales para la formación de una conciencia religiosa en la infancia, basada en la angustia y el miedo a la muerte. Si analizamos cada una de estas imágenes, vemos que se acompañan de un relato rápido de las andanzas del rey correspondiente que, si había desarrollado en su vida unos fuertes valores morales, solía morir en su cama, acompañado de los suyos y de un sacerdote, mientras que, si se caracterizó por la violencia y la injusticia, acababa su vida de forma brutal y espantosa. Esto también explicaría la enorme, aunque gradualmente decreciente, importancia que se le da a los reyes godos - 21 imágenes en 1867, 14 en 1878 y 5 en Calleja-, cuyas vidas y muertes agitadas daban ocasión para multitud de reflexiones morales. La disminución de las láminas de esta etapa supuso un incremento de las dedicadas a la Reconquista y la Edad Media, pues el espacio dedicado a la etapa que comenzó a partir de los Reyes Católicos era prácticamente similar en las tres colecciones, con 47 imágenes en 1867, 41 en 1878 y 44 en Calleja (véase fig. 5).

Podemos encontrar una diferencia fundamental en el tratamiento que de la Edad Media y la reconquista realizan las tres colecciones. Todas ellas respetan el protagonismo de los diferentes reinos, pero las dos primeras dedican mucha más atención a la monarquía de Castilla, "que, tiempo andando, debía cubrir dos mundos con sus gloriosas banderas" (González, 1867: 63). Sin embargo, la colección de Calleja tiene más láminas de Cataluña y Aragón que las anteriores, dedica dibujos especiales a Wifredo el Velloso y al origen del escudo catalán, y recoge muchísimas más escenas de carácter local y que afectan a las tradiciones inventadas de muchas poblaciones españolas. Aunque detrás de ello quizás hubiera una estrategia comercial, también pudiera ser la manifestación de un modelo nacionalista propio del regeneracionismo conservador, que en otra ocasión denominé "la España varia" y que construía la identidad nacional a partir de la "patria chica", es decir, del reconocimiento de la pluralidad de las regiones y pueblos de España (Pozo, 2000: 200-224).

En las tres colecciones de láminas históricas es prácticamente invisible la España Imperial. El descubrimiento de América merece sólo un dibujo en las dos primeras, en las que 
nunca más se vuelve a hacer referencia a las expediciones españolas, salvo por una breve alusión a Oceanía. La etapa de los siglos XVI y XVII ve oscurecido su brillo imperial por el escaso entusiasmo con que se valoraba a sus protagonistas, adoptándose con ello el punto de vista del historicismo liberal que consideraba "funesta" la era de la Casa de Austria (Álvarez y De la Fuente, 2010: 34) iniciada con Carlos I, a quien se dibujaba en Yuste expiando sus pecados y asistiendo a sus propios funerales, y continuada con Felipe II, de quien se destacaba el encarcelamiento de Antonio Pérez, dando así pábulo a la famosa "leyenda negra" contra la que Julián Juderías clamaría tanto desde 1914 (Juderías, 1914a y b). Calleja se despachaba con unos pocos dibujos dedicados a Pizarro y Hernán Cortés. Claro, que también se pasaba de puntillas por los procesos emancipatorios de las naciones americanas, aunque aludiéndose — sólo en el texto explicativo de González (1867) - a la "emancipación de los países que poseía España en el nuevo mundo" y a la independencia de Estados Unidos, "que subsiste todavía". Láminas y explicaciones posiblemente estaban pensadas para convencer

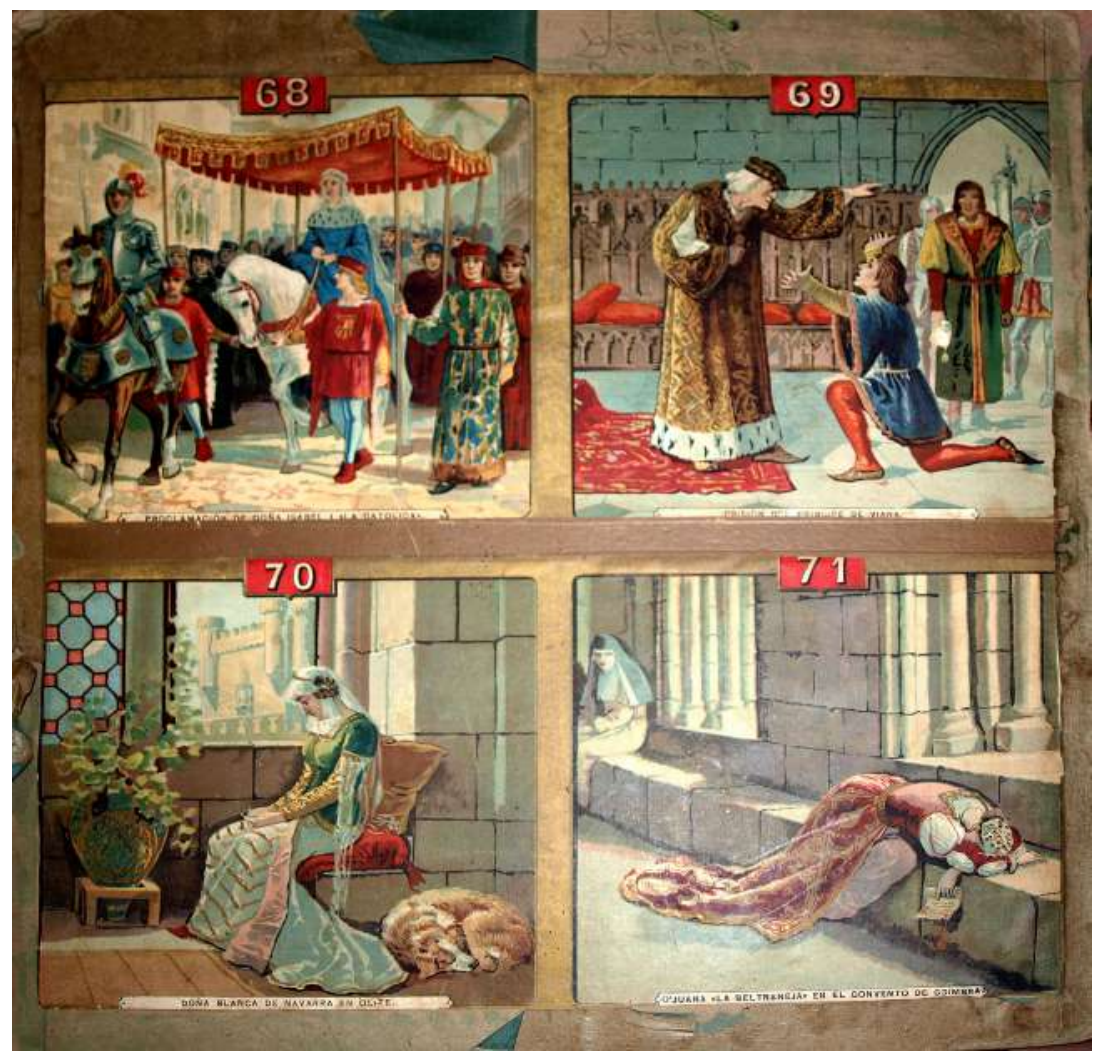

Figura 5. Imágenes de la colección Calleja, entre las que se encuentra la de la proclamación de la reina Isabel la Católica. 
a los niños de lo efímero y pasajero de los poderes terrenales, frente a lo eterno de los espirituales.

Las veinte últimas láminas de cada serie se dedicaban al siglo XIX, girando aproximadamente la mitad de ellas en torno a la invasión francesa y sus consecuencias. Las imágenes servían de refuerzo de una tradición, aún en proceso de gestación, de héroes y patriotas, y así, por ejemplo, en la colección de González (1867), el dibujo mostraba a una mujer en el centro de la defensa de Zaragoza, acompañada de un fraile, pero el texto explicativo no mencionaba siquiera su nombre, Agustina de Aragón, que, sin embargo, en la posterior colección de Calleja era ya apodada "la heroína de Zaragoza". En todas había una imagen de la promulgación de la Constitución de Cádiz, que en Conzález (1867) mostraba a una colección de prohombres, en una sutil identificación con la nueva clase política y con la burguesía que surgiría de este nuevo régimen liberal, mientras que en Calleja se representaba con un sacerdote, al lado del altar, y dirigiendo su palabra, con "actitud majestuosa", a un auditorio entregado. Ninguna de las tres colecciones de láminas parecía identificarse con la invención liberal de España, ni con sus símbolos y protagonistas. Riego aparecía en el momento de su ejecución, Mariana Pineda era dibujada inmediatamente antes de la suya, en la capilla, insinuándose como su rasgo más característico su condición de granadina y andaluza. Más bien

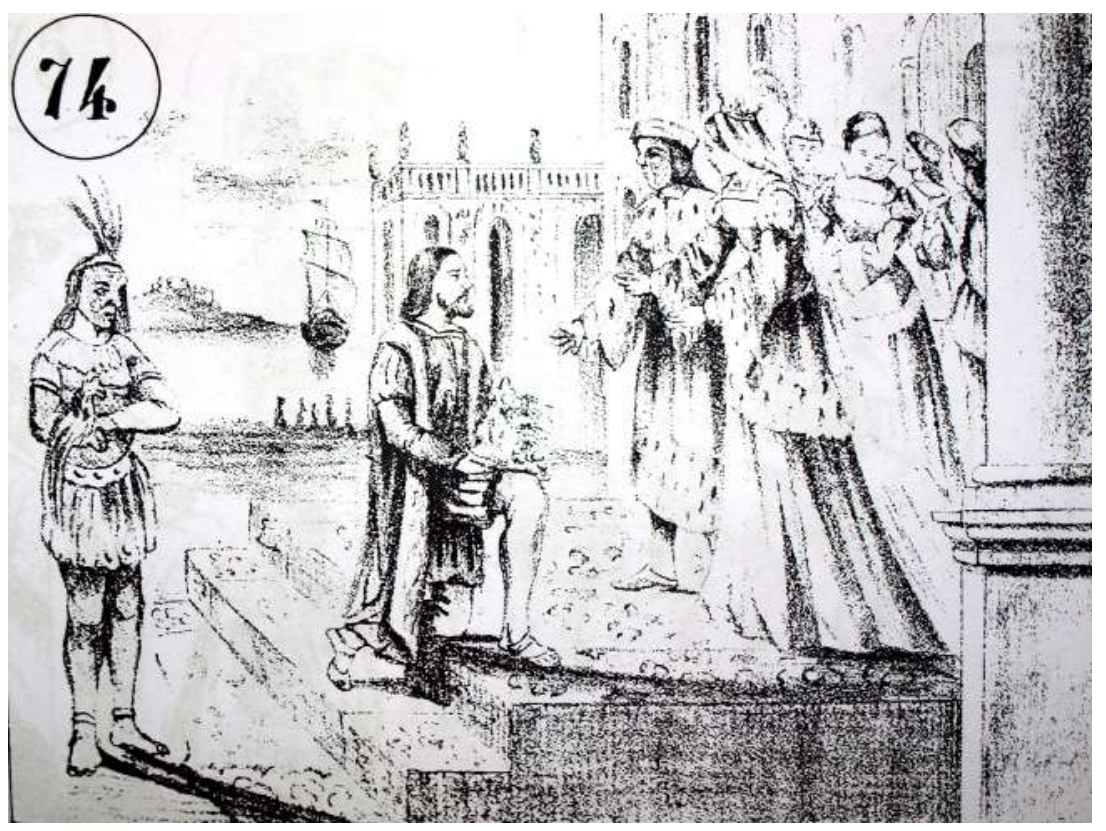

Figura 6. Presentación de Colón ante los Reyes Católicos, acompañado de los tesoros y de un indígena del Nuevo Mundo (González, 1867). 
se recordaba de los orígenes fundacionales del liberalismo el hambre, la pobreza, el cólera y las matanzas de frailes. Con leves alusiones a las últimas conquistas en Marruecos - ¿comienzo de la nostalgia por el pasado imperial perdido? - y al bombardeo del Callao acababan las dos primeras de estas colecciones. La de González y Ferriz (1878) tenía como última lámina un retrato de Alfonso XII y su primera esposa, $M^{a}$ de las Mercedes, después de haber obviado, casi totalmente, el reinado de Isabel II y silenciado todo el Sexenio Democrático. La de Calleja, que concluía con el fallecimiento del mismo rey, en 1885, sí que se había detenido, muy someramente, en Amadeo de Saboya y en el momento de la proclamación de la Primera República en el Parlamento, aunque sus explicaciones eran muy concisas y carecían totalmente de juicios valorativos. En definitiva, y salvo algunos destellos inusitados de liberalismo, las tres colecciones se ajustaban fielmente a los contenidos históricos aceptados por la historiografía conservadora decimonónica.

\section{Las láminas de historia de la civilización: hacia la construcción impensada de una Europa común}

El Museo Pedagógico Nacional elaboró desde 1913 informes sobre el material de enseñanza que debería adquirir el Ministerio de Instrucción Pública y Bellas Artes, que empezó en 1912 a incluir una partida anual en sus presupuestos para estas dotaciones. Las únicas colecciones de láminas que recomendó, a partir de 1915, fueron las de Historia de la Civilización elaboradas en Alemania por Lehmann y Lohmeyer. Pero esta sugerencia tuvo un cierto impacto, pues desde 1915 se comenzó una política de adquisiciones de material escolar que seguía, en líneas generales, las indicaciones del Museo Pedagógico Nacional. Para la enseñanza de la Historia en las escuelas primarias las láminas que se eligieron fueron, fundamentalmente, las de Lehmann. Según los expedientes de los concursos convocados por las autoridades ministeriales, llegaron a comprarse, entre 1921 y 1930, 390 ejemplares de esta colección, comercializados por diferentes empresas y con características y precios muy variados. En la etapa republicana se dejó de pedir, no sólo la serie de Lehmann, sino casi todo el material adecuado para la enseñanza de la Historia. Sin embargo, esta compilación debió tener bastante difusión en las escuelas españolas, quizás más en las privadas por su elevado precio, porque figuraba en muchos catálogos de material educativo del siglo xx (Catálogo, ¿1912?: 179; Catálogo, s.a.: 123; Esteva Marata, 1914: 157-158; Catálogo, 1925: 48 y Catálogo, 1934: 102). De hecho, así como la de Lohmeyer y otras muchas colecciones alemanas seguían teniendo sus textos y pies de lámina en el idioma original, de la de Lehmann se hicieron ediciones especiales adaptadas al castellano, y acabó perdiendo hasta el nombre de su autor, pues fue conocida simplemente por el nombre de "Historia de la Civilización". También 
debieron realizarse otras adaptaciones, porque los catálogos y las órdenes ministeriales hablaban de series con 12, 24, 25 y hasta 28 láminas, siendo así que la compilación manejada originalmente por el Museo Pedagógico Nacional llegaba a las 34. Quizás no sea muy aventurado suponer que, en la edición española, se suprimiesen las escenas más típicamente alemanas y se añadiese alguna otra más vendible en el mercado nacional, pudiéndo ser considerado éste un caso típico de cómo las láminas de Historia cruzaron fronteras y se redenominaron y se reinterpretaron.

Frente a los repertorios de Historia de España esta serie tenía la diferencia fundamental de incluir una sola y gran imagen en cada lámina, por lo que sus posibilidades didácticas eran muy amplias. Sin embargo, no me consta que nunca se elaborase un texto explicativo de los dibujos, por lo que la pequeña frase del pie de la lámina se convertía en el único referente para su entendimiento y difusión en las lecciones. Esta limitación dificultó enormemente su introducción y aplicación en las escuelas primarias, y, de hecho, carezco totalmente de datos sobre su utilización en las aulas, a pesar de la admiración y el interés que despertaron entre los pedagogos institucionistas e, incluso, entre los conservadores.

Una comparación entre algunas imágenes de las colecciones alemanas de Lehmann y las españolas que se reprodujeron en los catálogos no muestra absolutamente ninguna diferencia entre ellas. La mayoría recogían escenas de la cultura europea, que muchas veces hubieran podido ser adaptadas al caso español si lo hubiera permitido el conocimiento histórico que poseían los maestros. Así, la imagen primera de un castillo se denominaba en algunos catálogos con el título en alemán —Ritterburg-, en otros como "castillo de un caballero" y, finalmente, "castillo feudal". La colección se dedicaba sobre todo a la Edad Media y, quizás también por razones comerciales, se esforzaba por construir un pasado común en el que cualquier mención alemana acabó desapareciendo. Así, dos láminas que en algunos catálogos se definían como "de los tiempos de los antiguos alemanes", en otros figuraban como "alquimista" y "delante de la puerta de una ciudad" (véase fig. 7). Otros muchos asuntos, como "torneo", "sitio", "interior de una ciudad", "aposento en casa de un ciudadano", "en el patio del monasterio", "investidura de un vasallo", "en el tiempo de los gremios", o "el descubrimiento de la imprenta", describían momentos de la historia cultural europea bastante compartidos por todos los territorios. Incluso muchas de las láminas tenían temas religiosos - "abadía benedictina de San Galo", "escritura monjil", "gótico monacal" y "procesión"-, que podían ser también comunes, pues nada en la redacción de los títulos hacía intuir siquiera la existencia de una reforma protestante. Un juicio de la época de Carlomagno acabó convirtiéndose en un "tribunal sinodal" sin ninguna apelación al emperador carolingio. Sin embargo, a pesar de estos cambios en el texto, el visionado de las láminas que se correspondían con estos pies nos hace pensar que, si bien no se identificaban con "lo alemán", tampoco lo hacían con "lo español", por más que los editores denominasen con el españolísimo término de "cortijo" a una vivien- 


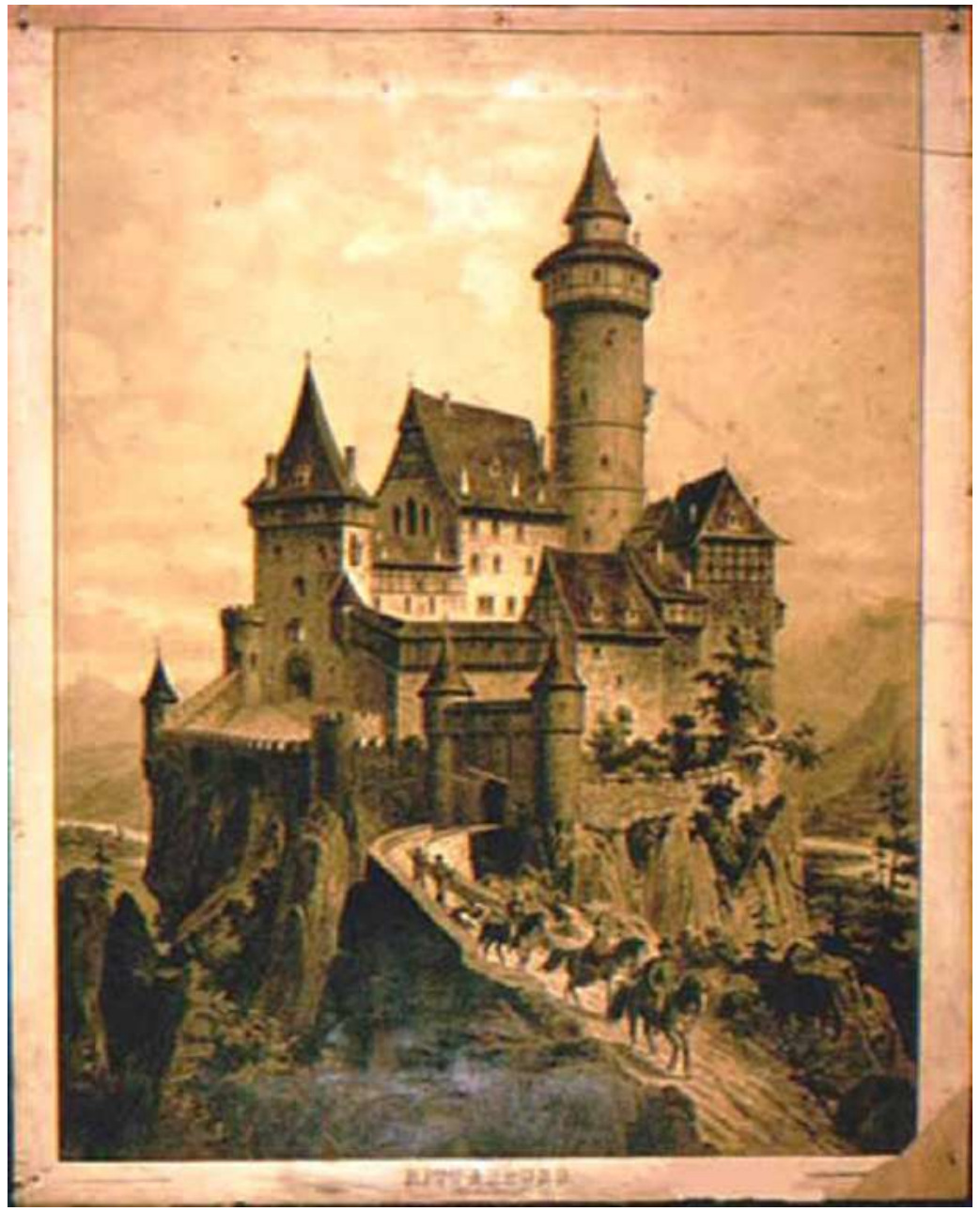

Figura 7. Ritterburg o "castillo de un caballero", en la colección de láminas de Historia de la Civilización de Lehmann

da germana primitiva. No todas las editoriales ofrecían las mismas escenas, aunque había al menos un 70 por ciento de contenido común, y una de las que seguramente se ofreciese en especial para el mercado español era la de "La Alhambra".

Sería interesante llegar a conocer si la producción y difusión masiva de este material en los diferentes países llegó a generar una imagen de Europa como historia compartida y memoria cultural de los ciudadanos europeos, a pesar de que muy posiblemente no fuera esa su intencionalidad original. Los tópicos y temas de las colecciones que circularon profusamente por todo el continente constituirían los hitos fundacionales para la construcción de 
una identidad europea, contraponiéndose a los manuales escolares, que relataban unas historias de marcado carácter nacionalista Todavía sigue siendo un camino inexplorado el cómo estas láminas se nacionalizaron y adaptaron a la cultura española desde las escuelas.

\section{Bibliografía}

Altamira, Rafael (1891), La enseñanza de la Historia, Madrid, Fortanet. (1934), "La enseñanza de la Historia en las escuelas", en Museo Pedagógico Nacional, La enseñanza de la Historia en las escuelas, Madrid, Imp. de E. Maestre, pp. 37-57.

Álvarez Junco, José y De la Fuente Monge, Gregorio (2010), "Orígenes Mitológicos de España". Ponencia presentada en el Seminario de Historia del Instituto Universitario José Ortega y Gasset. Documento (pdf) disponible en: <http://www.ucm.es/info/historia/ortega/7-10.pdf> (consulta: 27/01/2012)

Ballesteros, Antonio y Fernando Sáinz (1934), Organización Escolar, Madrid, Publicaciones de la Revista de Pedagogía.

Ballesteros y Márquez, Francisco (1899), Educación, Didáctica Pedagógica y Práctica de la Enseñanza, Córdoba, Imp. La Región Andaluza.

Bastinos, Antonio J. (1897), Catálogo ilustrado de los productos de esta casa fundada en 1852. Libros y material escolar, Barcelona, Antonio J. Bastinos.

Bouza, Fernando (2008), "Por no usarse. Sobre uso, circulación y mercado de imágenes políticas en la alta Edad Moderna", en Joan Lluís Palos y Diana Carrió-Invernizzi (dirs.), La Historia imaginada. Construcciones usuales del pasado en la Edad Moderna, Madrid, Centro de Estudios Europa Hispánica.

Carderera, Mariano (1863), La Pedagogía en la Exposición Universal de Londres de 1862, Madrid, Imp. de Don Victoriano Hernando.

Calleja Fernández, Saturnino (1901), Explicacion de las láminas de Historia de España publicadas por Saturnino Calleja, Madrid, Imp. L.Aguado.

(1911), Catálogo de la Casa Editorial Saturnino Calleja Fernández, 1876-1911, Madrid, Bernardo Rodríguez.

Castillo Yurrita, Alberto del (¿1929?), Gráfico de la Historia de España, Barcelona, A. Martín (una hoja de $75 \times 108 \mathrm{~cm})$.

Catálogo (1909), Catálogo de las obras de Primera Enseñanza y libros de consulta y de utilidad para los maestros. Material de enseñanza y mobiliario escolar para toda clase de Establecimientos docentes. Madrid, Imp. de Perlado, Páez y Ca.

__ (s.a.) (¿1912?), Catálogo general de obras de Primera Enseñanza, de texto y consulta, científicas, literarias, de Medicina, Derecho y material de escuelas, Barcelona, J. Ruiz Romero, Librería HispanoAmericana de J. Ruiz Romero (Sucesor de J. Bastinos).

(1934-1935), Catálogo de material escolar, Gerona-Madrid, Casa Editorial Dalmáu Carles, Pla.

(1925), Catálogo de Material Pedagógico Moderno, Madrid, Juan Eimler.

(s.a.), Catálogo ilustrado de material de Enseñanza. Lista de los aparatos y útiles más modernos y adecuados para la enseñanza objetiva aprobado y en uso en las escuelas de Alemania, 2a ed., Barcelona, Seix y Barral Hnos.

(1934), Catálogo no 30. Material Pedagógico Moderno, Madrid, Eimler-Basanta-Haaser.

Catteeuw, Karl (2005), Als de muren konden spreken... Schoolwandplaten en de geschidenis van het lager ondenwijs, Lovaina, Bélgica, Centrum voor Historische Pedagogiek. 
Catteeuw, Karl (2009), "Tinted history". Ponencia presentada en el congreso "Wall charts, history and European identity" (Würzburg, 2-3 de abril de 2009), documento html disponible en: <http:// historywallcharts.eu/congress/whoiswho.html> (consulta: 27/01/2012).

Cavanna, François (2003), Sur les murs de la classe, París, Hoëbeke.

Cobos, Francisco Javier (1869), Estudios crítico-históricos y administrativos sobre la parte pedagógica de la Exposición Universal celebrada en París en 1867, Granada, Lib. de D. Paulino Ventura y Sabatel.

Cossío, Manuel Bartolomé (1915), La enseñanza primaria en España, $2^{a}$ ed., Madrid, Imp. de Ricardo Rojas.

Costa Rico, Antón (2006), "El ajuar en la escuela", en Agustín Escolano Benito (dir.), Historia ilustrada de la Escuela en España. Dos siglos de perspectiva histórica, Madrid, Fundación Germán Sánchez Ruipérez, pp. 197-218.

Costes, Adela (ap. 1830), Cuadro simbólico de la historia de España, o sea historia de España con sus divisiones, hechos, fechas, \&. Traducida en signos materiales y aprendida por el órgano de la vista. In folio (450 × 350 mm). 20 láminas en cobre con dibujos explicativos. En Casa del Sr. Verdaguer y en la de D. Manuel Sauró, Barcelona. Las 20 láminas, si estuvieran montadas, formarían un cuadro de $225 \times 140 \mathrm{~cm}$.

Costes, Adela (1842), Compendio de la Historia de España o Guía del Mapa simbólico para el nuevo método de estudiar la Historia, por el cual se aprenden traducidos en signos emblemáticos los principales acontecimientos y las más memorables épocas de los reinados, etc., Trad. al español por D. Luís Bordas, Barcelona, Imp. de J. Verdaguer.

Dane, Jacques, Sarah-Jane Earle y Tijs Van Ruiten (2011), "The Material Classroom", en Sjaak Braster, lan Grosvenor y María del Mar del Pozo Andrés (eds.), The Black Box of Schooling. A Cultural History of the Classroom, Bruselas, Peter Lang.

Dane, Jacques (ed.) (2009), Jetses aan de wand, Kampen, Omniboek.

Depaepe, Marc (2005), "Speaking of Wall Charts. On the occasion of the thematic exhibition in the Municipal Museum of Education in Ypres", documento pdf disponible en: <http://www.simposium2005.ch/depaepe_fr_tl-ref.pdf > (consulta: 20/04/2009).

Escolano Benito, Agustín (2007), "La cultura material de la escuela", en Agustín Escolano Benito (ed.), La cultura material de la escuela. En el centenario de la Junta para Ampliación de Estudios, 1907-2007, Soria, Gráficas Varona, pp. 15-27.

(2008), "La cultura de la escuela. Una interpretación etnohistórica", Memoria, conocimiento y utopía, núm. 5, pp. 119-134.

Esteva Marata, Jacinto (1914), Catálogo General Ilustrado de material instructivo moderno para escuelas elementales y normales, Institutos, Universidades, etc., etc., Barcelona, J. Esteva Marata.

Exposition Universelle de 1867 (1867), Catalogue Générale de la Section espagnole Publié par la Commissión Royale d'Espagne, París, Imprimerie Générale de Ch. Lahore.

González, J. (1867), La Historia de España en láminas. Cronología de los hechos y reinados hasta nuestros días o sea el texto explicativo de la gran colección en 120 casos que comprende. Madrid, Museo de la Educación.

González y Ferriz (1878), Historia de España. Colección de láminas que representan los hechos más notables de la misma, Madrid, Lib. de González y Ferriz.

Grever, Maria (2010), "History wall charts: Scenes from a shared European past or images of history learning in Europe?", EUROCLIO Bulletin, núm. 30, pp. 64-69.

Historic Wall Chart Website, portal disponible en: <http://historywallcharts.eu> (consulta: 27/01/2012).

Institut National de Recherche Pédagogique (2009), Voir/Savoir. La Pédagogie par l'image aux temps de l'imprimé (du XVle au XXe siècle), Ruan, Francia, Musée National de l'Éducation. 
Juderías y Loyot, Julián (1914a), La leyenda negra. Estudios acerca del concepto de España en el extranjero, Barcelona, Casa Editorial Araluce. (1914b), La leyenda negra y la verdad histórica, Madrid, Tip. de la Rev. de Arch., Bibl. y Museos.

Lawn, Martin y lan Grosvenor (2005), "The Materiality of Schooling", en Martin Lawn e lan Grosvenor (eds.), The Materialities of Schooling, Oxford, Symposium Books, pp. 7-17.

Maestro González, Pilar (2005), "La idea de España en la historiografía escolar del siglo xIX", en Antonio Morales Moya y Mariano Esteban de Vega (eds.), ¿Alma de España? Castilla en las interpretaciones del pasado español, Madrid, Marcial Pons, pp. 141-194.

Maslowski, Ralf (2001), School Culture and School Performance, Enschede, Twente University Press.

Mediano y Ruiz, Baldomero (1878), Compendio de la Historia de España, dispuesto para servir de texto explicativo a la colección de láminas publicada por Ferriz y Sánchez y de libro de lectura en las escuelas, Madrid, Lib. de González y Ferriz.

Menéndez Pidal de Navascúes, Faustino, O’Donnell, Hugo y Lolo, Begoña (1999), Símbolos de España, Madrid, Centro de Estudios Políticos y Constitucionales.

Miró, Ignacio Ramón (1889), La enseñana de la Historia en las escuelas, Barcelona, Juan Bastinos.

Museo Pedagógico de Instrucción Primaria (1890), Catálogo provisional, Madrid, Fortanet.

Museo Pedagógico Nacional (1915), Notas sobre material de enseñanza, Madrid, R.F. de Rojas.

Pozo Andrés, María del Mar, del (2000), Currículum e Identidad Nacional. Regeneracionismos, nacionalismos y escuela pública (1890-1939), Madrid, Biblioteca Nueva.

Rosado, Manuel (1882), Exposición Pedagógica Primera en España. Catálogo de los objetos de enseñanza presentados para una escuela modelo, Madrid, Imp. del Centro Bibliográfico.

Ruiz Berrio, Julio (dir.), Anastasio Martínez Navarro, Carmen Colmenar y Myriam Carreño (2002), La editorial Calleja, un agente de modernización educativa en la Restauración, Madrid, UNED-Biblioteca Manes.

Ruiz Castell, Pedro (2008), "Scientific Instruments for Education in Early Twentieth-Century Spain", Annals of Science, vol. 65, núm. 4, pp. 519-527.

Serrano de Haro, Agustín (1933), Metodología de la enseñanza de la Historia, Madrid, FAE.

Sobrino y Dorado, Eugenio (1882), Exposición Pedagógica en 1882. Escuela rural, Madrid, Imp. de Fernando Cao y Domingo de Val.

Stach, Reinhard (2000), "Wandbilder als Didaktische Segmente der Realität", Paedagogica Historica: International Journal of the History of Education, vol. 36, núm. 1, (Supplementary Series, Marc Depaepe y Bregt Henkens (eds.), "The Challenge of the Visual in the History of Education"), pp. 199-221.

Terrón Bañuelos, Aida y Ángel Mato Díaz (1992), Un modelo escolar integrador y reformista: la FundaciónEscuelas Selgas, Oviedo, KRK ediciones.

Uphoff, Katharina (2009), "Europe and identity-Wall charts, history and European identity". Ponencia presentada en el congreso "Wall charts, history and European identity" (Würzburg, 2-3 de abril de 2009), documento html disponible en: <http://historywallcharts.eu/congress/whoiswho.html> (consulta: 27/04/2010).

Van Oostrom, Frits Peter (ed.) (1998), Historisch tableau: geschiedenis opnieuw verbeeld in schoolplaten en essays, Amsterdam, Amsterdam University Press.

Willems, Herbert W.G.M. (1996), "Het hangt aan de muur en sticht. Beschavingsidealen in de negentiende eeuw en de schoolplaten van Hendrik Jan van Lummel", De negenliende eeuw, núm. 20, pp. 185-191.

Zapater Cornejo, Miguel (2007), Escuelas de indianos en La Rioja, Logroño, Instituto de Estudios Riojanos. 
María del Mar del Pozo Andrés, Universidad de Alcalá (España). Es doctora en Filosofía y Ciencias de la Educación, Catedrática de Universidad de Teoría e Historia de la Educación. sus líneas de investigación son: educación y construcción de identidades nacionales, etnohistoria de la escuela y de la cultura escolar, historia de la educación urbana y movimientos internacionales de educación y su recepción en contextos nacionales.

Publicaciones recientes: Gabriela Ossenbach Sauter y $\mathrm{M}^{\mathrm{a}}$ del Mar del Pozo Andrés (eds.), Lost Empires, Regained Nations: Postcolonial Models, Cultural Transfers and Transnational Perspectives in Latin America (1870-1970), número monográfico de Paedagogica Historica: International Journal of the History of Education, vol. 47, núm. 5, septiembre-octubre, 2011.; Ma del Mar del Pozo Andrés y Teresa Rabazas Romero: "Exploring new concepts of popular education: Politics, religion and citizenship in the suburban schools of Madrid (Spain), 1940-1975", Paedagogica Historica: International Journal of the History of Education, vol. 47, núms. 1 y 2 , febrero-abril, 2011, pp. 221-242.

Recibido: 30 de enero de 2012

Aceptado: 22 de octubre de 2012 